\title{
Removal of Chromium from Chromium(VI) Solutions by Adsorption and Reduction Using Immobilized Persimmon Gel
}

\author{
Takehiko Tsuruta and Tomonobu Hatano \\ Department of Mechanical and Biochemical Engineering, Faculty of Engineering, Graduate School of Hachinohe Institute of \\ Technology, Hachinohe Aomori 031-8501, Japan
}

Received: November 16, 2015 / Accepted: November 18, 2015 / Published: December 10, 2015

\begin{abstract}
The removal of chromium(VI) from an aqueous solution using persimmon gel was examined. The amount of chromium(VI) removed was strongly affected by the $\mathrm{pH}$ of the solution, with all chromium(VI) being removed at $\mathrm{pH} 2$ or lower. However, in a solution containing, $15 \mathrm{mg}$ dry weight of immobilized persimmon gel, the amount of removed chromium(VI) decreased as the $\mathrm{pH}$ increased. A part of chromium(VI) was reduced another oxidation stage, mainly chromium(III), by immobilized persimmon gel. The amount of reduced chromium(III) in the solution was increased with decreasing the $\mathrm{pH}$ of the solution. As a result, the amount of total chromium removed was maximal at $\mathrm{pH} 2$. The amount of chromium removed were affected by the chromium concentration and the amount of gel. The maximal amount of chromium removed by the column system was also discussed.
\end{abstract}

Key words: Chromium removal, immobilized persimmon gel, adsorption, Langmuir isotherm, chromium reduction.

\section{Introduction}

Chromium is used in textile, leather tanning, electroplating, metal finishing industries [1], wood treatment, corrosion control, oxidation and anodizing industries. If high levels of chromium are absorbed by the body, it can generate serious problems and concentration of $100 \mathrm{~g} / \mathrm{g}$ body wt. can ultimately become lethal [2]. Recently, the main processes for elimination of chromium have been adsorption, reverse osmosis, and chemical reactions that involve reduction and precipitation [1]. Among these processes, adsorption has been shown to be a feasible method for removing traces of chromium from wastewater and many different adsorbents have been tried to remove this toxic metal from wastewater [1-3].

Adsorption is the most effective and widely used technique for the removal of toxic heavy metals

Corresponding author: Takehiko Tsuruta, Ph.D., research fields: metal removal and recovery using biomass. from wastewater [4]. Owing to the high cost and difficult procurement of activated carbon, efforts are being directed toward other finding efficient and low cost adsorbent substances [1]. A variety of low cost substances like fly ash, wood charcoal, bituminous coal, bagasse and coconut juice, rice husk carbon, peat, red mud, used black tea leaves, and activated carbon from sugar industrial waste have been examined [5-13].

Previously, microorganisms could be removed many kinds of toxic and useful metals, such as lithium, uranium, thorium, rare earths, and gold from aqueous solution [14-18]. However, microorganisms could remove only small amounts of chromium from the chromium(VI) solution. In other studies, immobilized persimmon gel could be removed gold(III) from hydrogen tetra chloroaurate(III) solution [19]. Further investigations showed that persimmon tannin gel removed chromium(VI) effectively from the chromium(VI) solution [20]. However, the amount of 
adsorbed chromium(VI) and the amount of residual chromium(III) remaining in the solution were not examined in detail [20]. Herein, the removal of chromium from aqueous chromium(VI) solution using immobilized persimmon gel is extended and reported.

\section{Material and Methods}

\subsection{Immobilization of Persimmon Tannin}

Commercially available kakishibu (the extracted juice of unripe persimmon fruit, tannin content: $4.0 \%$ ) was immobilized as follows: one part of glutaraldehyde was mixed with four parts of persimmon tannin. After $2 \mathrm{~h}$, a red-wine-colored homogeneous gel was obtained. The gel was crushed into small particles (less than 60 mesh), washed thoroughly with deionized water, and then used for removal experiments.

\subsection{Chromium Removal Experiments}

Unless otherwise stated, chromium removal experiments using immobilized persimmon gel were conducted as follows: batch system: the gel was suspended with $100 \mathrm{~mL}$ of aqueous chromium solution and stirred at room temperature using magnetic stirrer (120 rpm). Chromium was supplied as $\mathrm{K}_{2} \mathrm{Cr}_{2} \mathrm{O}_{7}$ or $\mathrm{Cr}\left(\mathrm{NO}_{3}\right)_{3}$. The $\mathrm{pH}$ of the solution was adjusted to the desired values with 0.1 mol $\mathrm{HNO}_{3}$ or $\mathrm{NaOH}$ over the range of $\mathrm{pH} 1-5$. The gels were then collected by filtration through a membrane filter (pore size $0.2 \mu \mathrm{m}$ ). Column system: unless otherwise stated, $1,510 \mathrm{~mL}$ of gold solution $(53.1 \mathrm{mg} / \mathrm{L}$ chromium (as $\mathrm{K}_{2} \mathrm{Cr}_{2} \mathrm{O}_{7}$, pH 2) was passed through a column (diameter $8 \mathrm{~mm}$, bedvolume $3.9 \mathrm{~mL}$ ) of immobilized persimmon gel at a Space Velocity (SV) of $15.7 \mathrm{~h}^{-1}$.

The amounts of removed chromium(VI) were quantified by the diphenyl carbazide method [21] by measuring the absorbance of the solution at $540 \mathrm{~nm}$ using spectrophotometer (U-1800, Hitachi). The amounts of removed total chromium were determined by atomic absorption spectrometer (AA-6300, Shimadzu, Kyoto).

\section{Results and Discussion}

3.1 Effect of pH on Chromium Removal from Aqueous Chromium(VI) Solution Using Immobilized Persimmon Gel

The effect of $\mathrm{pH}$ (over the range of $\mathrm{pH} 1-5$ ) on the removal of chromium(VI) was examined by immobilized persimmon gel from an aqueous solution of chromium(VI) as $\mathrm{K}_{2} \mathrm{Cr}_{2} \mathrm{O}_{7}$ (Fig. 1). The chromium(VI) removal from the potassium bichromate(VI) solution was quantitative at $\mathrm{pH}$ 1-2. Above $\mathrm{pH}$ 2, rapid decreases in the amount of chromium(VI) removed was observed. In the same solution, the total chromium removal was maximal at $\mathrm{pH}$ 2. Above and below $\mathrm{pH} 2$, rapid and gradual decreases of total chromium removal were observed (Fig. 1).

The chromium(VI) (\%) remaining in solution increased with increasing the $\mathrm{pH}$ of the solution. On the other hand, the amount of reduced chromium(III) in the solution increased as the acidity of the solution decreased. By subtracting the amount of total chromium(\%) removed from the amount of removed chromium(VI) (\%), the amount of chromium(VI) was reduced to chromium(III) in the solution. Reduced chromium(III) was the chemical species of chromium present in solution at $\mathrm{pH}$ 1-2 after removal of chromium(VI). The removal of chromium(VI) using persimmon gel was also investigated [20], however, this is the first finding to clarify the amount of reduced chromium(III) from chromium(VI) in the solution in this system.

Using a solution of chromium(III) nitrate, the role of $\mathrm{pH}$ on chromium(III) removal by immobilized persimmon gel was also examined (Fig. 2). The amount of chromium(III) removed increased as the $\mathrm{pH}$ of the solution increased. At $\mathrm{pH}$ values less than $\mathrm{pH} 3$, this adsorbent could not remove any chromium(III) from solution.

The chemical species of chromium(VI) in the bichromate(VI) solution is mostly hydrogen chromate anion, $\mathrm{HCrO}_{4}^{-}$at $\mathrm{pH}$ 1-5 [23]. 


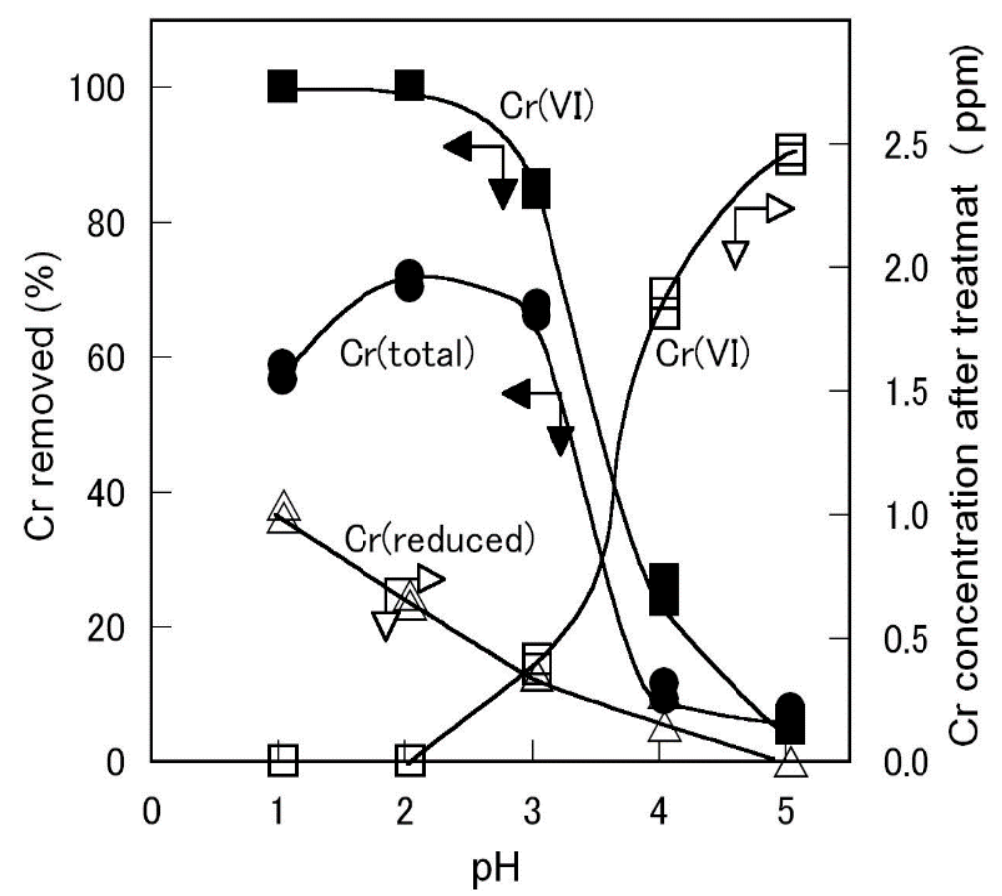

Fig. 1 Effect of $\mathrm{pH}$ on the removal and reduction of chromium(VI) from the potassium bichromate(VI) solution using persimmon tannin absorbent.

Adsorbent (15 mg, dry wt. basis) was suspended in $100 \mathrm{~mL}$ of the potassium bichromate(VI) solution containing $2.5 \mathrm{ppm}$ of chromium(VI) for $1 \mathrm{~h}$ at room temperature, the $\mathrm{pH}$ of the solutions was not controlled in all of the experiments.

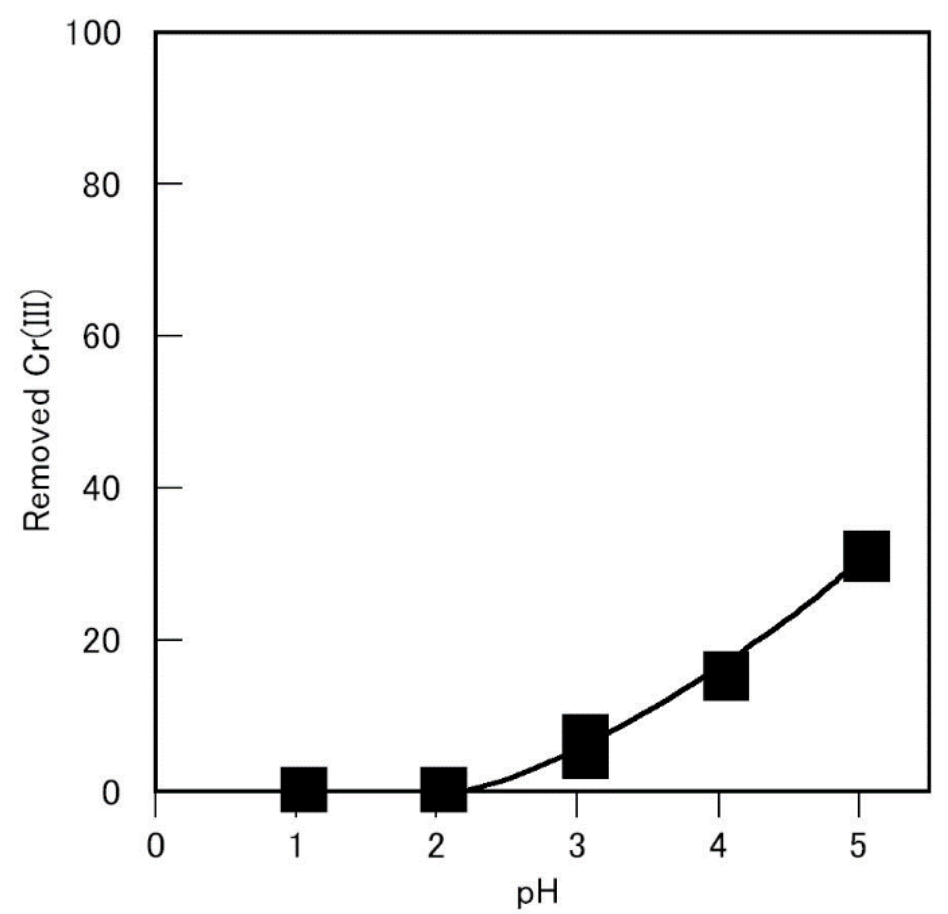

Fig. 2 Effect of $\mathbf{p H}$ on the removal of chromium from the chromium(III) nitrate solution by persimmon tannin absorbent. Adsorbent $(15 \mathrm{mg}$, dry wt. basis) was suspended in $100 \mathrm{~mL}$ of the chromium(III) nitrate solution containing $2.5 \mathrm{ppm}$ of chromium(III) for $1 \mathrm{~h}$ at room temperature. 


$$
\begin{gathered}
\mathrm{Cr}_{2} \mathrm{O}_{7}^{2-}+\mathrm{H}_{2} \mathrm{O} \rightleftharpoons 2 \mathrm{HCrO}_{4}^{-} \\
\mathrm{HCrO}_{4}^{-} \rightleftharpoons \mathrm{CrO}_{4}^{2-} \rightleftharpoons \mathrm{H}^{+}
\end{gathered}
$$

It seems reasonable that dichromate anion $\mathrm{Cr}_{2} \mathrm{O}_{7}{ }^{2-}$ was generated from potassium bichromate, followed by hydrolysis generated $\mathrm{HCrO}_{4}^{-}$. The equilibrium constant of Eq. (1) and acid dissociation constant of Eq. (2) were $10^{-1.68}$ and $10^{-6.45}$, respectively [22]. $\mathrm{HCrO}_{4}{ }^{-}$is dominantion between $\mathrm{pH}$ 1-5. Chromate anion $\mathrm{CrO}_{4}{ }^{2-}$ is increased and $\mathrm{HCrO}_{4}{ }^{-}$is decreased as the $\mathrm{pH}$ values of the solution increase up to $\mathrm{pH} 5$. Therefore, the removed chromium(VI) species in this research was mainly in the form of $\mathrm{HCrO}_{4}{ }^{-}$.

The chemical structure of persimmon tannin was proposed from dimer to pentamer of epigallocatechingallate-epigallocatechingallate-epicate chingallate-epigallocatechin-epigallocatechin-epicatec hin [23]. This compound contains two 1,2-dihydroxyphenyl (catechol) and seven 1,2,3-trihydroxyphenyl (pyrogallol) groups, acting as hard bases, in each chemical formula unit [23]. They should combine with $\mathrm{HCrO}_{4}^{-}$, in similar with $\mathrm{CrO}_{2}{ }^{2+}$ as a hard acid [20], and easily produce chromate ester [24]. Therefore, the removal of chromium(VI) appeared to proceed mainly through esterification of $\mathrm{HCrO}_{4}^{-}$ and catechol or pyrogallol group in persimmon gel.

On the other hand, this adsorbent has a high tendency toward being a reductant. Additionally, chromium(VI) has high tendency toward accepting
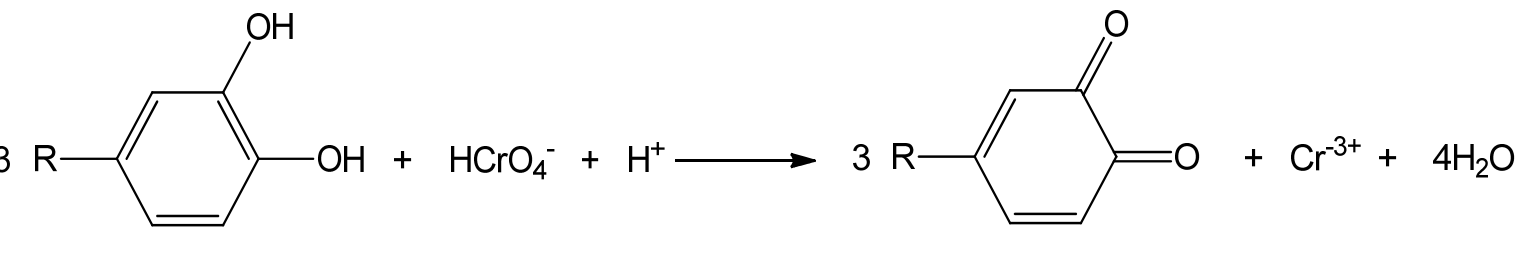

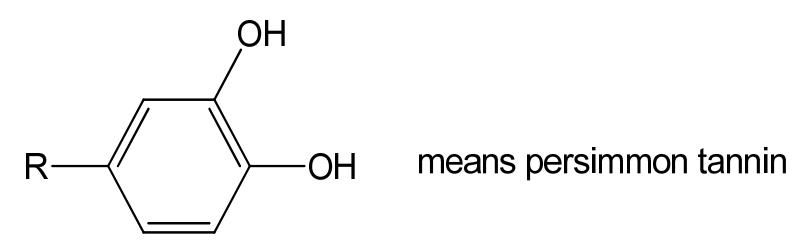

Fig. 3 Oxidation and reduction of persimmon tannin and chromium(VI) in the solution in this system. 


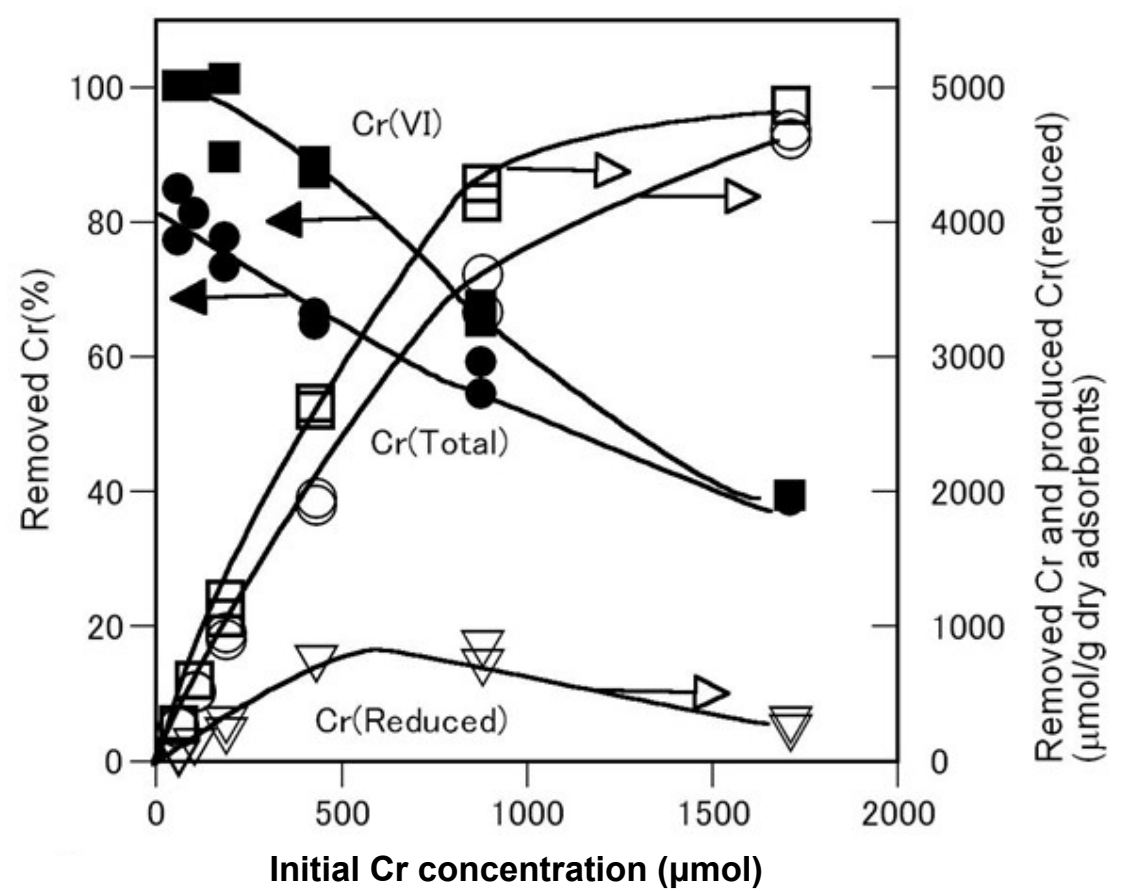

(a)

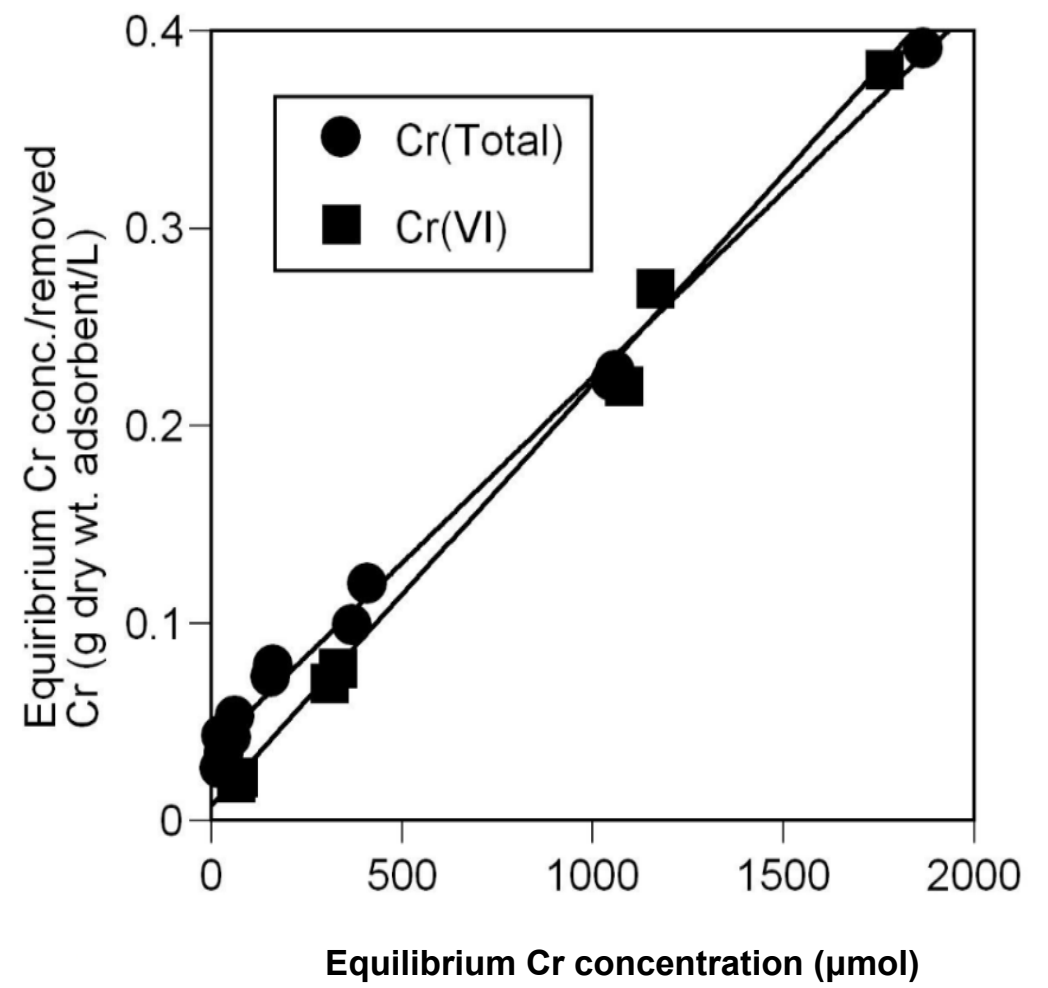

(b)

Fig. 4 (a) Effect of chromium concentration on chromium(VI) removal and reduction using immobilized persimmon tannin adsorbent and (b) equilibrium Langmuir isotherm of chromium removal using immobilized persimmon tannin adsorbent.

Adsorbent (15 mg dry wt. basis) was suspended in $100 \mathrm{~mL}$ of the solution (pH 2) containing indicated amounts of chromium(VI) for $1 \mathrm{~h}$ at room temperature. Symbols: squares, removed chromium(VI), circles, removed chromium (total) and triangles, produced chromium(III). 
Table 1 Estimated constants and $Q_{\max }$ from the Langmuir isotherm.

\begin{tabular}{llll}
\hline & $M$ & $N$ & $Q_{\max }(\mu \mathrm{mol} / \mathrm{g}$ dry wt. adsorbents) \\
\hline Chromium(VI) & $(2.13 \pm 0.01) \times 10^{-4}$ & $(7.97 \pm 4.74) \times 10^{-3}$ & $4,700 \pm 140$ \\
Chromium (total) & $(1.88 \pm 0.02) \times 10^{-4}$ & $(3.64 \pm 0.45) \times 10^{-2}$ & $5,320 \pm 40$ \\
\hline
\end{tabular}

* Experimental condition was same as Fig. 4.

contained 400-800 $\mu \mathrm{mol}$ chromium. Under these conditions, a gradual decrease in removal from the solutions containing above $800 \mu \mathrm{mol}$ and below 400 $\mu$ mol of chromium was observed.

\subsection{The Effect of the Adsorbent Amount on Chromium Removal Using Immobilized Persimmon Gel}

The quantity of immobilized persimmon gel adsorbent was varied over the range of 5-50 mg dry weight and measured chromium removal from a solution that initially contained $5 \mathrm{ppm}$ of chromium (Fig. 5). As the amount of adsorbent increased, the amount of chromium removed (expressed as $\mu \mathrm{mol}$ chromium/g dry wt. adsorbents) decreased, while the ratio of chromium removed/initial chromium concentration (\%) increased. The amounts of total reduced chromium increased as the amount of adsorbent increased, however, the amounts of reduced chromium (expressed as $\mu \mathrm{mol} / \mathrm{g}$ dry wt. adsorbents) were maximal in the presence of $10-15 \mathrm{mg}$ of absorbents (dry wt. basis).

\subsection{Time Course of Chromium Removal with Immobilized Persimmon Gel}

Adsorption of chromium(VI) was very rapidly and reached equilibrium within two hours (the residual

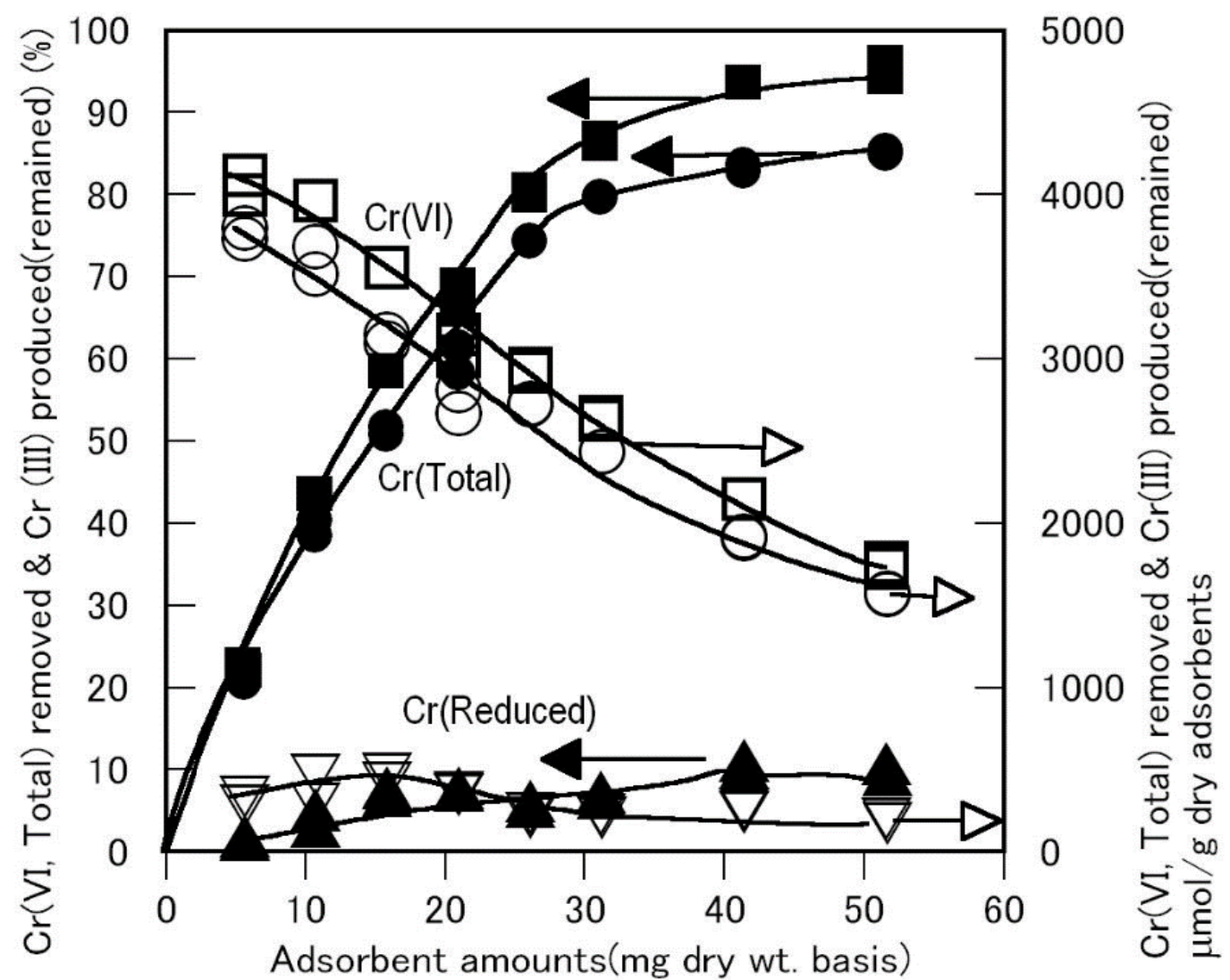

Fig. 5 Effect of adsorbent amounts on chromium removal and reduction using immobilized persimmon tannin gel.

The adsorbent was suspended in $100 \mathrm{~mL}$ of the solution $(\mathrm{pH} 2)$ containing $5 \mathrm{ppm}$ of chromium(VI) for $1 \mathrm{~h}$ at room temperature. Symbols were same as Fig. 4. 


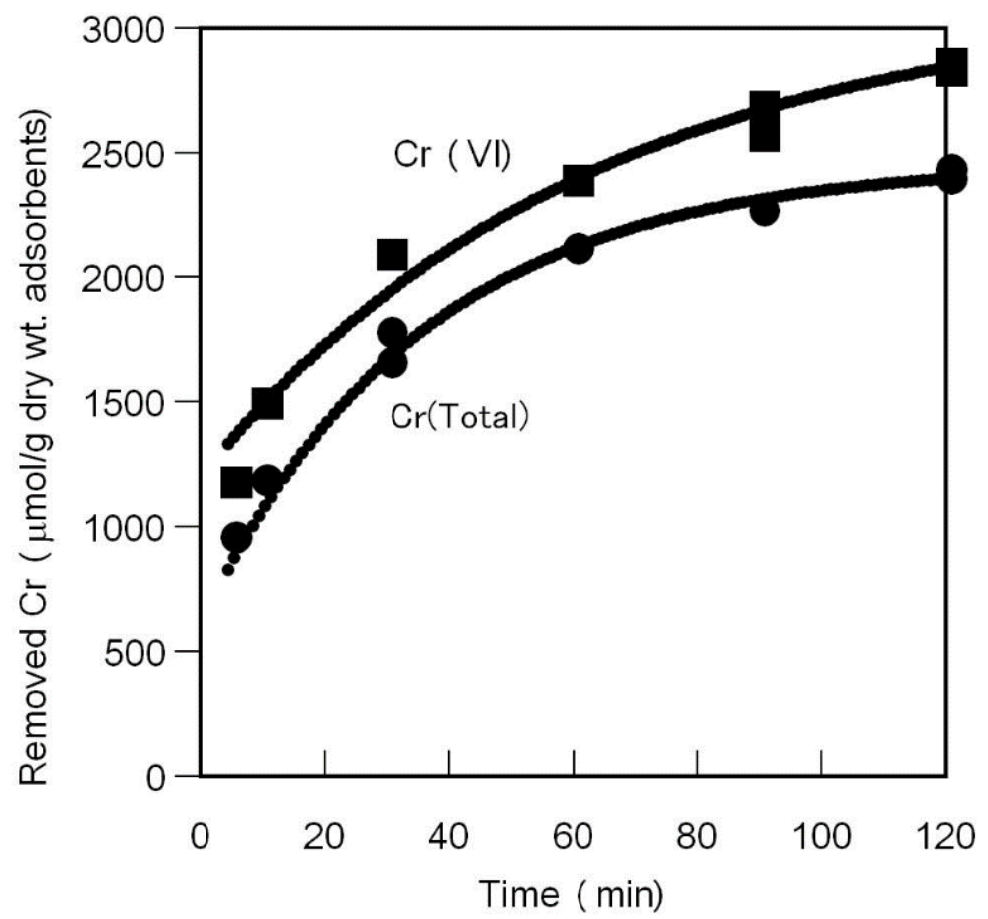

Fig. 6 Time course of chromium removal and reduction using immobilized persimmon tannin gel.

Adsorbent (15 mg, dry wt. basis) was suspended in $100 \mathrm{~mL}$ of the potassium bichromate(VI) solution containing $25 \mathrm{ppm}$ of chromium(VI) at room temperature, the $Q_{e}$ value used was determined by experimental data.

concentration of chromium(VI) at 17 hours was almost same as that at 2 hours) (Fig. 6). Reduction of chromium(VI) was a little lower than the adsorption. These results were fitted by an adsorption model using time-dependent Langmuir equation (Eq. (4)) [25]:

$$
\mathrm{Q}=Q_{e}\left(1-e^{-j t}\right)
$$

Where, $Q$ is the amount of the chromium removed, $Q_{e}$ is the removal amount of equilibrium, $j=k_{a}+k_{d}$, $k_{a}$ is the adsorption rate constant, and $k_{d}$ is the desorption rate constant [25]. The values of $Q_{e}$ and $j$ were estimated to be $2,450 \mu \mathrm{mol} / \mathrm{g}$ dry wt. adsorbents and $2.83 \times 10^{-2} \mathrm{~min}^{-1}$ for chromium (total) removal (adsorption and reduction), and $3,110 \mu \mathrm{mol} / \mathrm{g}$ adsorbents and $1.61 \times 10^{-2} \mathrm{~min}^{-1}$ for chromium(VI) removal (adsorption).

\subsection{Selective Removal of Chromium(VI) by Immobilized Persimmon Gel}

To determine which heavy metal ions can be most readily removed by immobilized persimmon gel at $\mathrm{pH} \mathrm{2,} \mathrm{selective} \mathrm{removal} \mathrm{of} \mathrm{heavy} \mathrm{metal} \mathrm{ions} \mathrm{from}$ a solution containing $4 \times 10^{-5} \mathrm{~mol} \mathrm{Mn}^{2+}, \mathrm{Co}^{2+}$, $\mathrm{Ni}^{2+}, \mathrm{Cu}^{2+}, \mathrm{Zn}^{2+}, \mathrm{Cd}^{2+}$ and $\mathrm{HCrO}_{4}^{-}$was examined. As shown in Fig. 7, the relative degree of heavy metal ion adsorption by immobilized persimmon gel was observed to be $\mathrm{HCrO}_{4}^{-}>$others, indicating that immobilized persimmon gel can remove chromium(VI) more readily than other heavy metal ions.

\subsection{Chromium Removal Capacity with Immobilized Persimmon Gel}

To obtain basic information about the recovery of chromium(VI) using persimmon gel, chromium(VI) removal was examined using column system. As shown in Table 2, immobilized persimmon gel adsorbed $313 \mathrm{mg}(6.01 \mathrm{mmol})$ and reduced $64 \mathrm{mg}$ (1.23 mmol) chromium(VI)/g dry wt. of immobilized persimmon gel. 


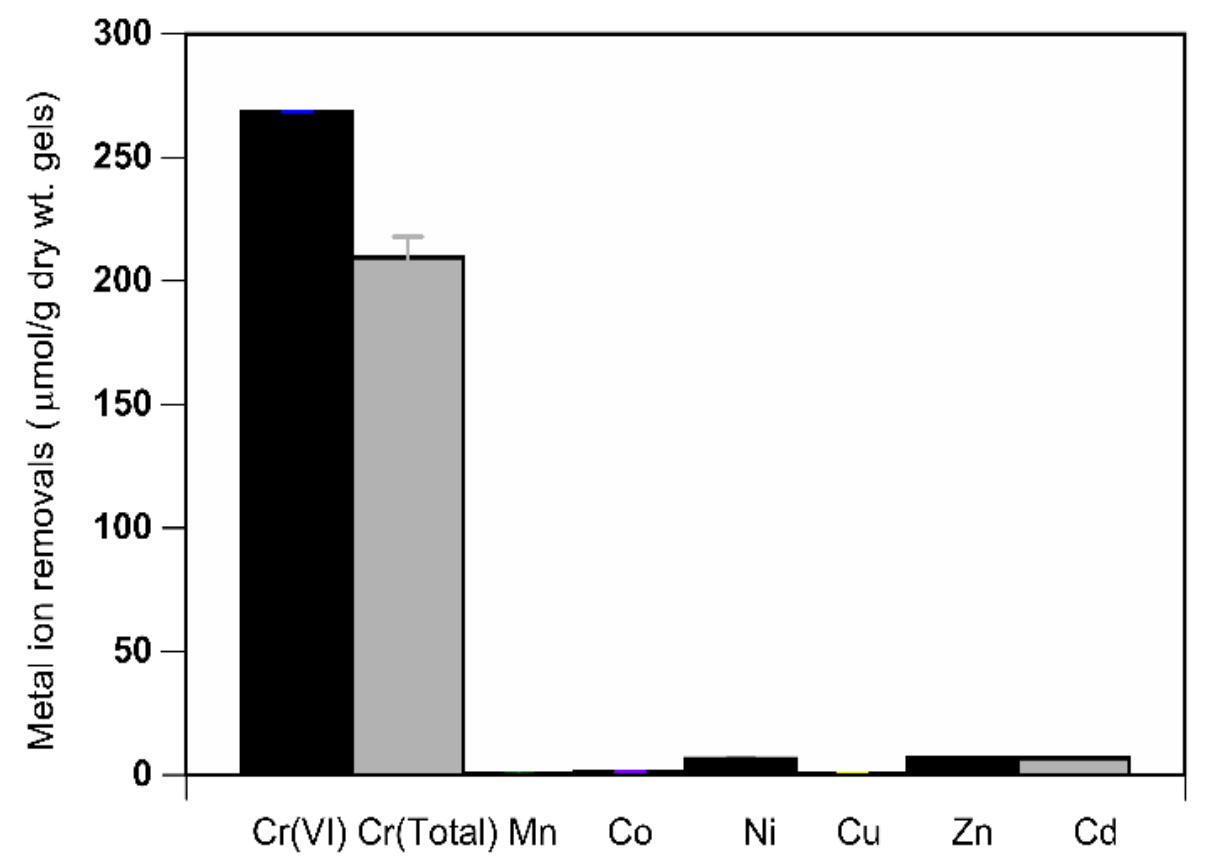

Fig. 7 Selective removal of heavy metals by immobilized persimmon gel.

Adsorbent (15 mg, dry wt. basis) was suspended in $100 \mathrm{~mL}$ of a solution ( $\mathrm{pH}$ 2) containing $4 \times 10^{-5} \mathrm{~mol} \mathrm{Mn}^{2+}, \mathrm{Co}^{2+}, \mathrm{Ni}^{2+}, \mathrm{Cu}^{2+}$, $\mathrm{Zn}^{2+}, \mathrm{Cd}^{2+}$ and $\mathrm{HCrO}^{4-}$ for $1 \mathrm{~h}$ at room temperature.

Table 2 Removal of chromium from aqueous chromium(VI) solution using immobilized persimmon gel by column system.

\begin{tabular}{lll}
\hline & Removed (\%) & Removed $(\mu \mathrm{mol} / \mathrm{g}$ dry wt. gels) \\
\hline Chromium(VI) & 89.7 & 7,280 \\
Chromium (total) & 69.2 & 5,620 \\
\hline
\end{tabular}

* Chromium(VI) solution (53.1 ppm, $1.51 \mathrm{~L}, \mathrm{pH}$ 2) was eluted on the persimmon gel column (bed volume $3.9 \mathrm{~mL}, 0.19 \mathrm{~g}$ dry wt. basis) at a space velocity of $15.7 \mathrm{~h}^{-1}$.

\section{Conclusions}

The removal of chromium using persimmon tannin adsorbent was strongly affected by the $\mathrm{pH}$ of the solution and at $\mathrm{pH} 2$, chromium(VI) removal was quantitative. At higher $\mathrm{pH}$ values, chromium(VI) removal decreased dramatically. The amount of total chromium removed was maximal at $\mathrm{pH} 2$, however, those were decreased with increasing or decreasing the $\mathrm{pH}$ of the solution. The positively charged protonated hydroxy groupes of the persimmon tannin and negatively charged hydrogen chromate ions were bonded at low $\mathrm{pH}$. Additionally, the amount of reduced chromium increased in low $\mathrm{pH}$ solutions.

The removal of chromium using immobilized persimmon tannin adsorbent was strongly affected by the initial chromium concentration of the solution.
Immobilized persimmon tannin adsorbent can remove chromium quantitatively from the solution containing lower $5 \mathrm{ppm}$ chromium(VI), however, the ratio of the amount of chromium(VI) removed with respect to the initial chromium(VI) concentration was decreased with increasing the initial chromium(VI) concentration. The amount of chromium $(\mu \mathrm{mol} / \mathrm{g}$ dry wt. adsorbents) was increased with increasing the initial chromium(VI) concentration of the solution. When the initial chromium(VI) concentration was $1,700 \mu \mathrm{mol}$, persimmon gel removed $4,860 \mu \mathrm{mol}$ of chromium(VI). The amount of chromium removed was fitted with Langmuir's isotherm. The amount of reduced chromium was maximal from the solution containing 400-800 $\mu \mathrm{mol}$ chromium(VI).

The removal of chromium using immobilized persimmon tannin absorbents was strongly affected by 
the adsorbent amounts. The ratio of the amount of removed chromium(VI) per that of initial chromium(VI) was increased with increasing the amount of adsorbent, however, the proportion of chromium removed ( $\mu \mathrm{mol} / \mathrm{g}$ dry wt. adsorbent) was decreased with increasing the amount of adsorbent. The amount of total reduced chromium was increased with increasing the amount of adsorbent, however, the amounts of reduced chromium $(\mu \mathrm{mol} / \mathrm{g}$ dry wt. adsorbent) was maximal using 10-15 mg of adsorbent (dry wt. basis).

Adsorption of chromium(VI) was very rapidly and reached equilibrium within two hours. Reduction of chromium(VI) was a little slower than adsorption. The time course of chromium removal was fitted by an adsorption model using time-dependent Langmuir equation.

The maximum amount of chromium(VI) removed was examined by a column system. Immobilized persimmon gel adsorbed $313 \mathrm{mg}(6.01 \mathrm{mmol})$ and reduced $64 \mathrm{mg}(1.23 \mathrm{mmol})$ chromium(VI)/g dry wt. of immobilized persimmon gel.

On the basis of this research, the removal of chromium(VI) from the aqueous systems should be feasible in the near future.

\section{References}

[1] Mohamed, Al-M., Hesham, G. I., and Mohamed, M. A. 2008. "Equilibrium and Kinetics of Chromium, Adsorption on Cement Kiln Dust." In Proc. World Cong. Eng. Comp. Sci., 54-62.

[2] Schneider, R. M., Cavalin, C. F., Barros, M. A. S. D., and Tavares, C. R. G. 2007. "Adsorption of Chromium Ions in Activated Carbon." Chem. Eng. J. 132: 355-362.

[3] Youssef, A. M., Nabarawy, T. E., and Samra, S. E. 2004. "Sorption Properties of Chemically Activated Carbons 1, Sorption of Cadmium(II) Ions." Colloids Surf. A 235: 153-163.

[4] Selvi, K., Pattabhi, S., and Kadirvelu, K. 2001. "Removal of Chromium(VI) from Aqueous Solution by Adsorption onto Activated Carbon.” Bioresour. Technol. 80: 87-89.

[5] Grover, M., and Narayanswamy, M. S. 1982. "Removal of Hexavalent Chromium by Adsorption on Fly Ash, Institution of Engineers." Indian J. Environ. Eng. 63: 36-39.
[6] Deepak, D. A., and Gupta, K. 1991. "Hexavalent Chromium Removal from Wastewater." Indian $J$. Environ. Health 33: 297-305.

[7] Kannan, N., and Vanangamudi, A. 1991. "A Study on Removal of Chromium(VI) by Adsorption Lignite Coal." Indian J. Environ. Pollut. 11: 241-245.

[8] Chand, S. V., Agarwal, K., and Pavankumar, C. 1994. "Removal of Hexavalent Chromium from Wastewater by Adsorption.” Indian J. Environ. Health 36: 151-158.

[9] Srinivasan, K., Balasubramaniam, N., and Ramakrishna, T. V. 1988. "Studies on Chromium Removal by Rice Husk Carbon." Indian J. Environ. Health 30: 376-387.

[10] Brown, P. A., and Allen, S. J. 2000. "Metal Removal from Wastewater Using Peat." Wat. Res. 34: 3907-3916.

[11] Gupta, V. K., Gupta, M., and Sharma, S. 2001. "Process Development for the Removal of Lad and Chromium from Aqueous Solutions Using Red Mud-An Aluminum Industry Waste." Water Res. 35: 1125-1134.

[12] Hossain, M. A., Kumita, M., Michigami, Y., and Mori, S. 2005. "Kinetics of Chromium(VI) Adsorption on Used Black Tea Leaves." J. Chem. Eng. Japanese 38: 402-406.

[13] Fahim, N. F., Barsoum, B. N., Eid, A. E., and Khalil, M. S. 2006. "Removal of Chromium(III) from Tannery Wastewater Using Activated Carbon from Sugar Industrial Waste." J. Hazard Mater 136: 303-309.

[14] Tsuruta, T. 2005. "Removal and Recovery of Lithium Using Various Microorganisms." J. Biosci. Bioeng. 100: 562-566.

[15] Tsuruta, T. 2002. "Removal and Recovery of Uranyl Ion Using Various Microorganisms." J. Biosci. Bioeng. 94: 23-28.

[16] Tsuruta, T. 2003. “Accumulation of Thorium ion Using Various Microorganisms.” J. Gen. Appl. Microbiol. 49: 215-218.

[17] Tsuruta, T. 2006. "Selective Accumulation of Light or Heavy Rare Earth Elements Using Gram-Positive Bacteria." Colloids and Surfaces B: Biointerfaces 52: 117-122.

[18] Tsuruta, T. 2004. "Biosorption and Recycling of Gold Using Various Microorganisms." J. Gen. Appl. Microbiol. 50: 221-228.

[19] Sakaguchi, T., Nakajima, A., Tsuruta, T. 1995. "Uptake and Recovery of Gold by Immobilized Persimmon Tannin." In Proceedings of the XIXth International Mineral Processing Congress, 49-52.

[20] Nakajima, A., and Baba, Y. 2004. "Mechanism of Hexavalent Chromium Adsorption by Persimmon Tannin Gel." Water Res. 38: 2859-2864.

[21] Aoyama, M., Sugiyama, T., Seki, K., Tuda, M., and Cho, N. S. 1999. "Removal of Hexavalent Chromium by Japanese Red Pine Leaves." J. Hokkaido For. Prod. Res. Inst. 13: 15-19. 
[22] Ishida, K., and Harada, M. 2004. "Adsorption and Desorption of Chromium(VI) on Active Carbon." Bunseki Kagaku (Written in Japanese) 53: 1061-1065.

[23] Matsuo, T., and Itoh, S. 1977. "About Persimmon Tannin (Kaki Tannin Wo Megutte).” Kagaku to Seibutsu (Written in Japanese) 15: 732-736.
[24] Nakano, Y., Takeshita, K., and Tsutsumi, T. 2001. "Adsorption Mechanism of Hexavalent Chromium by Redox within Condensed-Tannin Gel." Water Res. 35: 496-500.

[25] Kondoh, H., Ishikawa, T., and Adachi, I. 1988. Science of Adsorption. Tokyo: Maeuzen. 